Vol. 11 (2002): 371-379.

\title{
Phosphorus extractability in surface soil samples as affected by mixing with subsoil
}

\author{
Tommi Peltovuori \\ Department of Applied Chemistry and Microbiology, FIN-00014 University of Helsinki, Finland, \\ e-mail: tommi.peltovuori@helsinki.fi
}

\begin{abstract}
Samples taken from the plow layer (Ap horizon) and subsoil (B horizon) of six cultivated soil profiles were analyzed as original samples and as mixtures containing $25 \%$ or $50 \%$ material from the B horizon. Acid ammonium acetate extractable phosphorus, degree of phosphorus saturation (DPS), and a phosphorus Q/I-plot were determined for each sample and mixture to evaluate the effect of bulking of dissimilar materials on results and to assess the possibilities of reducing $\mathrm{P}$ solubility in P-enriched surface soils. The results obtained for the mixtures were compared with mass-weighed average results of the original samples. Measured values of DPS corresponded well and those of acetate-extractable $\mathrm{P}$ reasonably well to the estimated values, and the results were linearly correlated with the mass fraction of horizon B material in the mixed samples $\left(\mathrm{r}^{2}>0.85\right)$. Water-extractable $\mathrm{P}$ behaved dissimilarly; the equilibrium P concentration (EPC) estimated from the Q/I-plots decreased dramatically when the fraction of highly sorptive horizon B material increased in the mixture. The marked effect of subsoil material on EPC values may provide a technique to reduce potential losses of soluble $\mathrm{P}$ by deep tillage.
\end{abstract}

Key words: phosphorus, sampling, soil horizons, sorption isotherms

\section{Introduction}

In cultivated soils, phosphorus $(\mathrm{P})$ reserves may exhibit large vertical variability created by soil formation and $\mathrm{P}$ fertilization (Peltovuori et al. 2002). Steep gradients between adjacent soil horizons are relevant both in environmental and agronomic contexts, and their recognition is essential for representative soil sampling. Increasing minimum tillage cultivation may also add to the vertical stratification of soil and lead to enrichment of a shallow surface layer with fertilizer or manure $\mathrm{P}$.

Even though the relationship between soil test $\mathrm{P}$ and $\mathrm{P}$ concentration of runoff water is far from predictable, a high $\mathrm{P}$ content of surface soil due to intensive agriculture poses the highest risk for receiving waterbodies (Yli-Halla et al. 1995, Sibbesen and Sharpley 1997). High P status of soil increases the risk of losses of particulate $\mathrm{P}$ with erosion material as well as losses of 


\section{Peltovuori, T. Phosphorus in mixed soil samples}

soluble P released from soil to runoff water, irrespective of the runoff route. Algal-available $P$ in runoff waters from agricultural soils primarily consists of dissolved reactive $\mathrm{P}$ (Ekholm 1998); therefore, soils able to maintain a high concentration of soluble $\mathrm{PO}_{4}-\mathrm{P}$ in the water phase pose the highest immediate risk for eutrophication.

In noncalcareous soils, the $\mathrm{PO}_{4}-\mathrm{P}$ concentration of soil solution is determined by sorptiondesorption reactions on short-range-ordered oxide surfaces and can accurately be measured with a Q/I-plot technique. The technique gives a comprehensive picture of the solubility of $\mathrm{P}$ in a particular soil (Hartikainen 1991) but is not suitable for routine analyses. A less laborious approach used to estimate the $\mathrm{PO}_{4}$-P concentration in runoff waters from divergent soils is the concept of $\mathrm{P}$ saturation, which relates the molar concentrations of sorbed $\mathrm{P}$ to those of active $\mathrm{Fe}$ and Al in soil (e.g. Beauchemin and Simard 1999). The degree of $\mathrm{P}$ saturation (DPS) in surface soil has been shown to correspond to the $\mathrm{PO}_{4}-\mathrm{P}$ concentrations in surface runoff water in rain simulator experiments (Pote et al. 1999). The relationship between DPS and equilibrium P concentration is well established in the laboratory. Under field conditions, the complexity of related hydrological factors diminishes the correlation between runoff $\mathrm{PO}_{4}-\mathrm{P}$ and soil DPS. One of the key factors in field conditions is the depth of interaction between surface soil and water. Rainfall intensity, slope, plant cover, crop residues, and soil aggregation, among others, affect the depth of interaction (Sharpley 1985); generally, the effective interaction has been considered to occur in a layer ranging from millimeters to a few centimeters.

Due to the shallow layer of interaction between surface runoff and soil, sampling of only the top few centimeters is often recommended for environmental soil $\mathrm{P}$ analyses (Sharpley et al. 1978, Gartley and Sims 1994, Turtola and YliHalla 1999). This is reasonable if the $\mathrm{P}$ conditions in the immediate surface differ from those in the rest of the surface soil: a pattern not unexpected in grassland or no-till soils. Differences between the surface soil and subsoil horizons are practically always distinct. In both cases, too deep sampling leads to bulking of dissimilar materials in unknown ratios, and hence, to ambiguous soil test results. Despite the importance of sampling as part of soil P management, few studies have dealt with possible errors induced by improper sampling or bulking of original samples to composite samples. This study was conducted to explore the effects of bulking of dissimilar soil samples on results of various $\mathrm{P}$ analyses. Samples were taken from the Ap horizons and the respective $\mathrm{B}$ horizons to obtain clear contrasts. A secondary objective was to estimate possibilities of reducing environmental risks for $\mathrm{PO}_{4}-\mathrm{P}$ losses by mixing low $\mathrm{P}$ material from the subsoil with a P-enriched surface soil layer.

\section{Material and methods}

Six soil profiles were sampled according to genetic soil horizons. From each soil, the topmost Ap horizon (thickness 20-30 cm) and a B horizon starting at an approximate depth of $30 \mathrm{~cm}$ were used. Depths and selected characteristics of the horizons are given in Table 1. Prior to the analyses, the samples were sieved, homogenized, and stored at sampling moisture at $5^{\circ} \mathrm{C}$ in the dark. The analyses were carried out on original Ap and B horizon samples and on mixtures containing $25 \%$ or $50 \%$ (mass) of horizon B material. Mixtures were made in the extraction vessels by weighing appropriate amounts of the two materials for extraction. Field-moist samples were used in all analyses, but reported mixing ratios and extraction results are calculated on an oven-dry basis (gravimetric moisture at $105^{\circ} \mathrm{C}$ ).

Assuming a hypothetical $100 \%$ selectivity and specificity of the analyses, the results for soil sample mixtures (Y) were estimated as a mass-weighed average of the original Ap and B horizon sample results according to Equation 1:

(1) $Y=M_{A p}-\left(M_{A p}-M_{B}\right) \times X$, 
Vol. 11 (2002): 371-379.

Table 1. Selected properties of the soil horizons.

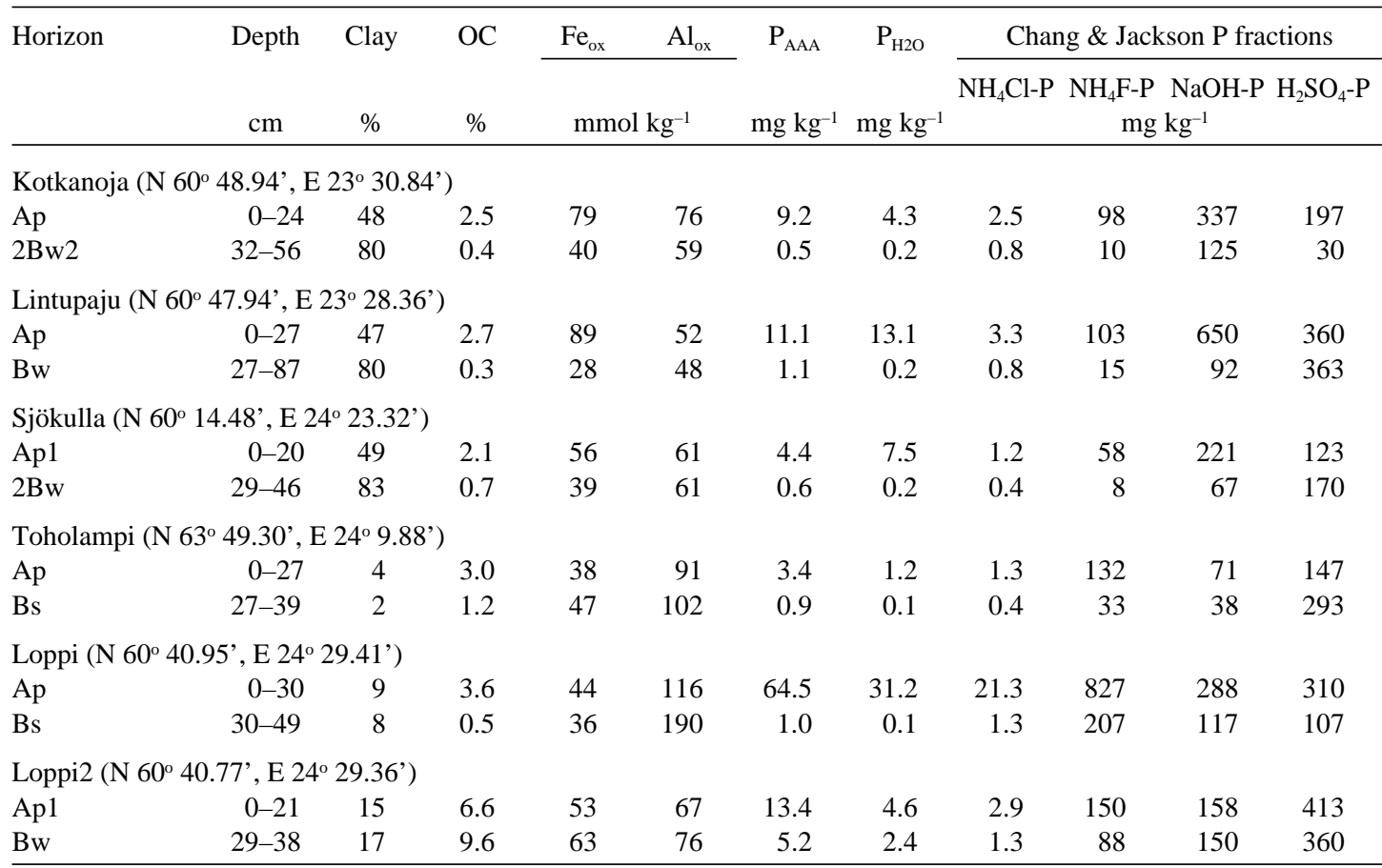

$\mathrm{OC}=$ organic carbon

where $M_{A p}$ and $M_{B}$ are measured results for the original $\mathrm{Ap}$ and $\mathrm{B}$ horizon samples and $\mathrm{X}$ is the mass fraction of horizon $B$ material in the mixture. The estimated results were compared with the values measured for actual soil sample mixtures.

Acid ammonium acetate extractable $\mathrm{P}\left(\mathrm{P}_{\mathrm{AAA}}\right)$ was determined in triplicate as in Vuorinen and Mäkitie (1955), with the exception that soil was weighed for the extractions and the results were calculated on a mass basis $\left(0.5 \mathrm{M} \mathrm{CH}_{3} \mathrm{COONH}_{4}\right.$, $0.5 \mathrm{M} \mathrm{CH}_{3} \mathrm{COOH}, \mathrm{pH} 4.65,1: 20 \mathrm{w}: \mathrm{v}, 1 \mathrm{~h}$ shaking). Chang and Jackson P fractions were determined in triplicate as in Hartikainen (1979): 1) easily soluble $\mathrm{P}$ was extracted with $1 \mathrm{M} \mathrm{NH}_{4} \mathrm{Cl}$ (1:50 w:v, 30 min shaking); 2) secondary P bound to $\mathrm{Al}$ oxides was extracted with $0.5 \mathrm{M} \mathrm{NH}_{4} \mathrm{~F}, \mathrm{pH}$ $8.5(1: 50,1 \mathrm{~h}) ; 3) \mathrm{P}$ bound to $\mathrm{Fe}$ oxides with $0.1 \mathrm{M} \mathrm{NaOH}(1: 50,16 \mathrm{~h})$; and 4) Ca-bound $\mathrm{P}$ with $0.25 \mathrm{M} \mathrm{H}_{2} \mathrm{SO}_{4}(1: 50,1 \mathrm{~h})$. The fractions are referred to as $\mathrm{NH}_{4} \mathrm{Cl}-\mathrm{P}, \mathrm{NH}_{4} \mathrm{~F}-\mathrm{P}, \mathrm{NaOH}-\mathrm{P}$, and
$\mathrm{H}_{2} \mathrm{SO}_{4}$-P. Short-range-ordered iron $\left(\mathrm{Fe}_{\mathrm{ox}}\right)$ and aluminum $\left(\mathrm{Al}_{\mathrm{ox}}\right)$ oxides were extracted, also in triplicate, with acid ammonium oxalate $(0.05 \mathrm{M}$ $\left(\mathrm{NH}_{4}\right)_{2} \mathrm{C}_{2} \mathrm{O}_{4} \cdot \mathrm{H}_{2} \mathrm{O}, \mathrm{pH} 3.3 ; 1: 20 \mathrm{w}: \mathrm{v} ; 2$ h shaking in the dark) (Niskanen 1989). Phosphorus fractions and oxalate-extractable $\mathrm{Al}$ and $\mathrm{Fe}$ were used to calculate the degree of P saturation (Peltovuori et al. 2002):

(2)

$$
\begin{aligned}
\text { DPS }= & \left(\mathrm{NH}_{4} \mathrm{Cl}-\mathrm{P}+\mathrm{NH}_{4} \mathrm{~F}-\mathrm{P}+\right. \\
& \mathrm{NaOH}-\mathrm{P})\left[\mathrm{mmol} \mathrm{kg}^{-1}\right] /(0.5 \times \\
& \left.\left(\mathrm{Al}_{\mathrm{ox}}+\mathrm{Fe}_{\mathrm{ox}}\right)\right)\left[\mathrm{mmol} \mathrm{kg}^{-1}\right]
\end{aligned}
$$

Phosphorus fractions were used in Equation 2 instead of oxalate-extractable $P$ because single oxalate extraction grossly overestimates the $\mathrm{P}$ saturation in Finnish soils (Uusitalo and Tuhkanen 2000, Peltovuori et al. 2002).

Phosphorus sorption characteristics of the samples were determined with a Q/I-plot technique at a soil-to-solution ratio of 1:50 using $\mathrm{P}$ 
Peltovuori, T. Phosphorus in mixed soil samples

a)

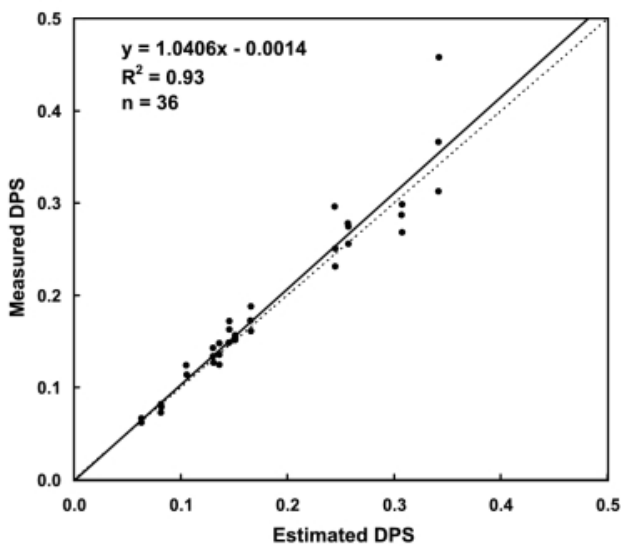

b)

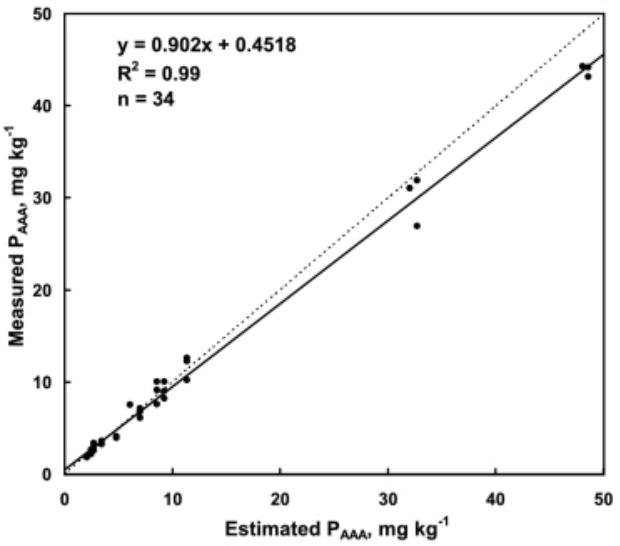

c)

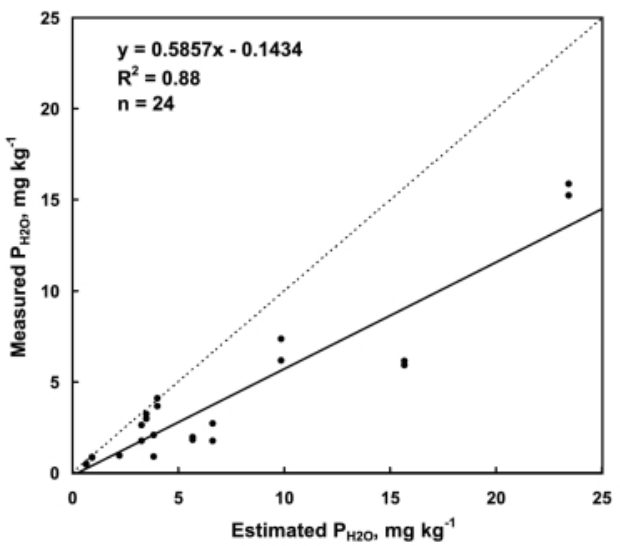

Fig. 1. Regression between measured values and the values estimated on the basis of individual soil sample results (Equation 1) of a) the degree of P saturation (DPS), b) acid ammonium acetate extractable $\mathrm{P}\left(\mathrm{P}_{\mathrm{AAA}}\right)$, and c) water-extractable $\mathrm{P}\left(\mathrm{P}_{\mathrm{H} 2 \mathrm{O}}\right)\left(\mathrm{mg} \mathrm{kg}^{-1}\right)$ for composite soil samples containing both Ap and $\mathrm{B}$ horizon material (fraction of horizon B material 0.25 or 0.50 ). additions of $0,0.5,1.0,1.5$, and $2.0 \mathrm{mg}^{-1}$ as $\mathrm{KH}_{2} \mathrm{PO}_{4}$ in a $\mathrm{H}_{2} \mathrm{O}$ matrix. After shaking the samples with solutions for $21 \mathrm{~h}$, the suspensions were filtered (Nuclepore ${ }^{\circledR}$ polycarbonate, $0.2 \mathrm{~mm}$ ) and the $\mathrm{PO}_{4}-\mathrm{P}$ concentrations of the filtrates determined with a molybdenum blue method. The amount of sorbed or desorbed $\mathrm{P}$ was calculated from the difference in the $\mathrm{P}$ concentration in the solution before and after the equilibration. A modification of the Freundlich adsorption equation $\left(\mathrm{Q}=\mathrm{Q}_{0}+\mathrm{k} \times \mathrm{I}^{\mathrm{n}}\right.$, Fitter and Sutton 1975) was fitted to the $\mathrm{Q} / \mathrm{I}$ points obtained in duplicate determinations, and the equations were used to calculate equilibrium phosphorus concentrations (EPC) (no net sorption or desorption of P). Coefficients of determination for the equations obtained ranged from 0.98 to 1.00 . Water-extractable $\mathrm{P}\left(\mathrm{P}_{\mathrm{H} 2 \mathrm{O}}\right)$ was measured from the Q/I-plot filtrates of zero $\mathrm{P}$ addition.

\section{Results}

Degrees of phosphorus saturation measured in the mixtures containing both Ap and B horizon materials agreed well with the estimates calculated with Equation 1 (Fig. 1a). The 95\% confidence interval for the regression coefficient in Fig. 1a (0.94-1.14) indicates no difference between measured and estimated values of DPS. Acetate-extractable $\mathrm{P}$ results for the mixtures, in contrast, deviated slightly from those estimated with Equation 1 (Fig. 1b). The regression coefficient excluded the value $1(0.88-0.93, \mathrm{P}=$ $0.95)$, indicating that at high $\mathrm{P}$ concentrations the measured values were lower than expected. In water extraction $\left(\mathrm{P}_{\mathrm{H} 2 \mathrm{O}}\right)$, the measured values for the mixed samples were distinctively lower than those estimated with Equation 1 (Fig. 1c, regression coefficient $0.49-0.68, \mathrm{P}=0.95)$. Coefficients of correlation both for DPS and $\mathrm{P}_{\text {AAA }}$ were also high compared with that of $\mathrm{P}_{\mathrm{H} 2 \mathrm{O}}$.

The behavior of DPS in mixed soil samples was close to ideal and that of acetate-extractable $\mathrm{P}$ was predictable (Fig. 1); in these cases, 
Vol. 11 (2002): 371-379.

Table 2. Linear regression equations between acid ammonium acetate extractable $P\left(P_{\text {AAA }}, \mathrm{mg} \mathrm{kg}^{-1}\right)$ and the mass fraction of horizon $\mathrm{B}$ material $(\mathrm{x})$ in the composite sample $(\mathrm{Ap}+\mathrm{B})$, and between the degree of $\mathrm{P}$ saturation (DPS) and the mass fraction of horizon B material in the composite sample.

\begin{tabular}{|c|c|c|c|}
\hline \multicolumn{2}{|l|}{ Soil } & \multirow[t]{2}{*}{$\mathrm{n}$} & \multirow[t]{2}{*}{$\mathrm{R}^{2}$} \\
\hline & $\mathrm{y}=\mathrm{P}_{\mathrm{AAA}}$ & & \\
\hline Kotkanoja & $y=8.88-8.69 x$ & 12 & 0.98 \\
\hline Lintupaju & $y=11.33-10.01 x$ & 10 & 0.95 \\
\hline Sjökulla & $y=4.38-3.85 x$ & 12 & 0.99 \\
\hline Toholampi & $y=3.39-2.60 x$ & 12 & 0.95 \\
\hline Loppi & $y=62.12-62.20 x$ & 12 & 0.98 \\
\hline Loppi2 & $y=13.49-8.40 x$ & 12 & 0.92 \\
\hline & $\mathrm{y}=\mathrm{DPS}$ & & \\
\hline Kotkanoja & $y=0.193-0.096 x$ & 12 & 0.86 \\
\hline Lintupaju & $y=0.360-0.253 x$ & 12 & 0.86 \\
\hline Sjökulla & $y=0.160-0.106 x$ & 12 & 0.94 \\
\hline Toholampi & $y=0.099-0.069 x$ & 12 & 0.97 \\
\hline Loppi & $y=0.460-0.372 x$ & 12 & 0.94 \\
\hline Loppi2 & $y=0.167-0.057 x$ & 12 & 0.85 \\
\hline
\end{tabular}

the use of Equation 1 is meaningful. The linear regression equations between measured acetateextractable P or DPS and the fraction of horizon B material in the composite samples are presented in Table 2. The fit of all equations was good $\left(r^{2}>0.85\right)$, and the regression coefficients as well as the constant terms of the equations were in accordance with the analytical results for the original Ap and B horizons ( $\mathrm{P}_{\mathrm{AAA}}$ in Table 1, DPS not shown) and Equation 1: the differences between the coefficients in Table 2 and those calculated on the basis of the results of original Ap and $\mathrm{B}$ horizons $\left[\mathrm{M}_{\mathrm{Ap}}\right.$ and $\left.\left(\mathrm{M}_{\mathrm{Ap}}-\mathrm{M}_{\mathrm{B}}\right)\right]$ were all less than $5 \%$.

As demonstrated in Fig. 1c, the behavior of water-extractable P differs from that of DPS and acetate-extractable $P$ because of the very high sorption affinities of the B horizons and consequent resorption of $\mathrm{P}$ in mixed samples during the extractions. Two-way desorption-resorption reactions during extraction result in a nonlinear behavior of water-soluble $\mathrm{P}$ in soil sample mixtures. This nonlinearity is evident in Fig. 2, which depicts the EPC values of composite soil samples as a function of the mixing ratio. Especially the high EPC values decreased dramati-

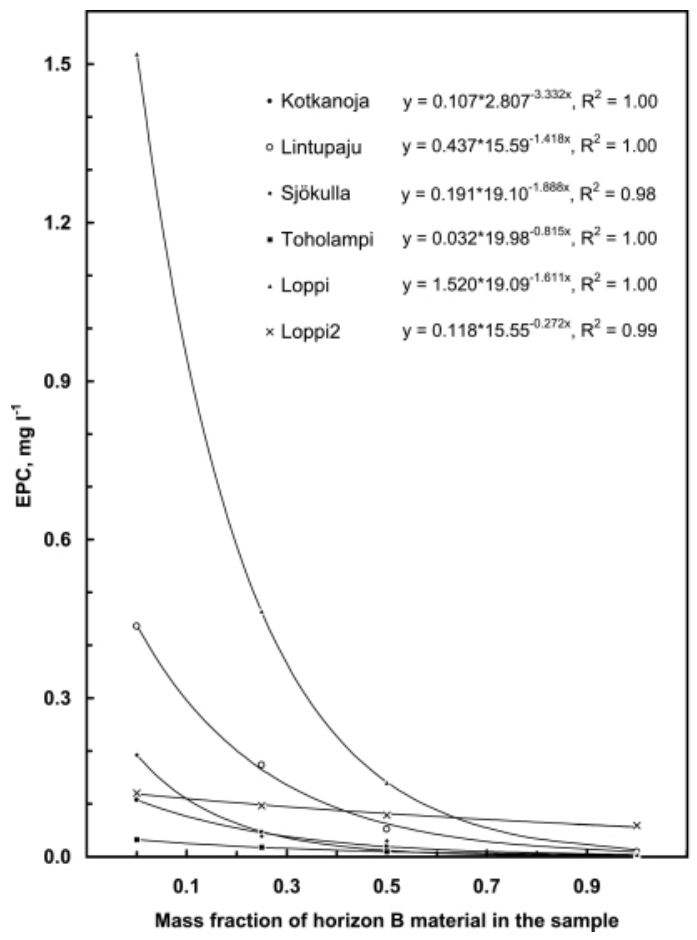

Fig. 2. Equilibrium phosphorus concentrations (EPC, mg $\left.1^{-1}\right)$ of composite soils samples with varying fractions $(0,0.25,0.50$, and 1.00$)$ of horizon $\mathrm{B}$ material in the sample. 


\section{Peltovuori, T. Phosphorus in mixed soil samples}

cally when subsoil material was added to the mixture. The values of the original $\mathrm{B}$ horizons were lower than $0.01 \mathrm{mg} \mathrm{l}^{-1}$, with the exception of the Loppi2 soil $\left(0.06 \mathrm{mg} \mathrm{l}^{-1}\right)$.

\section{Discussion}

The degree of P saturation (DPS) and acetateextractable $\mathrm{P}$ determined for a composite sample proved to be a mass-weighed average of the original samples. Thus, it can be estimated with Equation 1 if the results of the original samples and the mixing ratio are known. The predictable performance of these analyses is a consequence of net desorption of $\mathrm{P}$ from all mixed materials during the extraction. In the $\mathrm{P}$ fractionation used in the DPS determination, resorption is prevented by the strong extractants used. In the acid ammonium acetate extraction, the organic ligands of the extractant have a similar effect. At high $\mathrm{P}$ concentrations, however, the ability of the extractant to prevent resorption is insufficient and some resorption of $\mathrm{P}$ occurs, as can be seen from the regression coefficient in Fig. $1 \mathrm{~b}(<1)$. Resorption of $\mathrm{P}$ has been demonstrated to occur even with strong extractants when long extraction times are used (Rodrigues and Mendoza 1993). During water extraction or equilibration in Q/I-plot analyses, resorption from solution is probable to materials of high sorption affinity, leading to a nonlinear relationship between equilibrium $\mathrm{P}$ concentration and the mixing ratio. According to del Campillo et al. (1996), the possible deviations in $\mathrm{P}$ test results between a measured result of a composite sample and the calculated average of the original samples is highest when the samples differ in their intrinsic properties, e.g. sorption affinities.

The ranges of DPS (0.03-0.47) and acetateextractable $\mathrm{P}\left(0.5-71 \mathrm{mg} \mathrm{kg}^{-1}\right)$ measured in this study were large and cover the values typically encountered in the field - although values at the lower end of the scales were dominant. For both analyses, correlations between measured and estimated values for mixed samples (Fig. 1) were high, considering that the results of the original Ap and B horizon samples were excluded. These values were not included because Equation 1 returns the average result of Ap or B horizon when $\mathrm{X}$ is 0 or 1 , thus raising the correlation inappropriately. The values in Table 2 were calculated using all observations, including the results of the original samples.

The extensive use of moldboard plowing has created marked differences in $\mathrm{P}$ characteristics between Ap and B horizons in cultivated soils in Finland (Kaila 1963, Jokinen 1984, Puustinen et al. 1994). The boundary between the horizons is visually distinct and unintentional mixing of the horizons is usually easy to avoid in soil sampling. However, an apparently homogeneous Ap horizon may contain materials differing widely in P reserves; Humphreys et al. (1998) found up to $200 \%$ higher soil $\mathrm{P}$ test results in samples taken from the top $7.5 \mathrm{~cm}$ than in samples taken from the top $10 \mathrm{~cm}$ in the same grassland soils due to biological $\mathrm{P}$ translocation and surface fertilization or manuring. In Finland, a three-year surface application of slurry and $\mathrm{P}$ fertilizer on grass ley elevated the $P$ contents and acetate-extractable $\mathrm{P}$ in the top $5 \mathrm{~cm}$ of soil, while soil at 5-25 cm depth was unaffected (Turtola and Yli-Halla 1999). Placement of P fertilizers with planting creates distinct differences between the in-row and between-row soil test results (Urvas and Jussila 1979), but the differences disappear during the growing season. Minimum tillage practices may also create vertical stratification of nutrient concentrations, especially when combined with surface application of phosphorus. Howard et al. (1999) found distinctive $\mathrm{P}$ enrichment in the top $8 \mathrm{~cm}$ of soil after six years of no-till cotton farming. Further research on the most appropriate depth of sampling, as well as other aspects of representative sampling for environmental $\mathrm{P}$ analysis, is obviously required.

Water extraction has been suggested as a universal environmental soil $\mathrm{P}$ test for predicting $\mathrm{P}$ losses in surface runoff. Because of the rapid decrease in high EPC values with a small amount 
Vol. 11 (2002): 371-379.

of unintentional sorptive material in the sample, this analysis seems more vulnerable to errors induced by inappropriate soil sampling than the other two methods, acid ammonium acetate extraction and DPS. On the other hand, the nonlinearity between the concentration of $\mathrm{PO}_{4}-\mathrm{P}$ and the fraction of sorptive material in a mixture provides a promising technique to reduce the solubility and potential losses of $\mathrm{P}$ in $\mathrm{P}$-enriched topsoils: in the Loppi soil with an excessive P-test value, $25 \%$ of horizon $B$ material mixed with the Ap horizon decreased the EPC value by $70 \%$ with a simultaneous increase in buffering capacity. Success of the technique requires a B horizon of high P-fixing capacity. In the Loppi2 soil, the marginal decrease in the EPC values in mixed samples (Fig. 2) is most likely due to competitive sorption by soluble organic matter originating from the Bw horizon containing almost $10 \%$ organic carbon.

Of the several mandatory and voluntary measures currently used in reducing $\mathrm{P}$ loss from agricultural soils - fertilization limits, buffer zones, reduced tillage, constructed wetlands, and sedimentation ponds - only limiting the use of $\mathrm{P}$ focuses on the $\mathrm{P}$ release potential of the soil. Decreasing the area of high $\mathrm{P}$ content soils would be important in protecting the surface waters because the concentration of $\mathrm{PO}_{4}-\mathrm{P}$ in runoff waters is primarily controlled by the $\mathrm{P}$ status of surface soils (Yli-Halla et al. 1995). Unfortunately, high or excessive soil P-test values decrease slowly with existing $\mathrm{P}$ fertilization recommendations (Yli-Halla et al. 2001) and even with zero $P$ additions (Jaakkola et al. 1997). This laboratory study showed that on selected soils the leaching risk of the potentially most harmful form of $\mathrm{P}$ can be reduced quickly by mixing the surface soil with P-fixing subsoil. This remediation method could be applied on areas possessing high P-loss potential (hot spots). The method might even be attractive to some farmers since deep tillage has been shown to increase the accessibility of $\mathrm{P}$ by roots, and consequently cereal yields, on drought-prone clay soils (Saarela et al. 2000).

Acknowledgments. I thank the Finnish Drainage Research Foundation and the Finnish Cultural Foundation for financial support and Helena Soinne for the analytical work.

\section{References}

Beauchemin, S. \& Simard, R.R. 1999. Soil phosphorus saturation degree: Review of some indices and their suitability for $\mathrm{P}$ management in Québec, Canada. Canadian Journal of Soil Science 79: 615-625.

del Campillo, M.C., van der Zee, S.E.A.T.M. \& van Riemsdijk, W.H. 1996. Systematic bias in measuring intensities by selective extraction of bulked samples. Communications in Soil Science and Plant Analysis 27: 1829-1841.

Ekholm, P. 1998. Algal-available phosphorus originating from agriculture and municipalities. Monographs of the Boreal Environmental Research $11.60 \mathrm{p}$.

Fitter, A.H. \& Sutton, C.D. 1975. The use of Freundlich isotherm for soil phosphate sorption data. Journal of Soil Science 26: 241-246.

Gartley, K.L. \& Sims, J.T. 1994. Phosphorus soil testing: environmental uses and implications. Communications in soil science and plant analysis 25: 15651582.
Hartikainen, H. 1979. Phosphorus and its reactions in terrestrial soils and lake sediments. Journal of the Scientific Agricultural Society of Finland 51: 537-624.

Hartikainen, H. 1991. Potential mobility of accumulated phosphorus in soil as estimated by the indices of $Q /$ I plots and by extractant. Soil Science 152: 204-209.

Howard, D.D., Essington, M.E. \& Tyler, D.D. 1999. Vertical phosphorus and potassium stratification in no-till cotton soils. Agronomy Journal 91: 266-269.

Humphreys, J., Tunney, H. \& Duggan, P. 1998. Soil phosphorus determination using three extraction procedures, the effect of sampling depth and comparison of phosphorus recommendations for grassland. Irish Journal of Agricultural and Food Research 37: 2938.

Jaakkola, A., Hartikainen, H. \& Lemola, R. 1997. Effect of fertilization on soil phosphorus in a long-term field experiment in southern Finland. Agricultural and Food Science in Finland 6: 313-322. 
Peltovuori, T. Phosphorus in mixed soil samples

Jokinen, R. 1984. Comparison of and correlation between the characteristics of agricultural topsoil and subsoil at the southern coast of Finland. Journal of Agricultural Science in Finland 56: 245-254.

Kaila, A. 1963. Phosphorus conditions at various depths in some mineral soils. Journal of the Scientific Agricultural Society of Finland 35: 69-79.

Niskanen, R. 1989. Extractable aluminium, iron and manganese in mineral soils I. Dependence of extractability on the $\mathrm{pH}$ of oxalate, pyrophosphate and EDTA extractants. Journal of Agricultural Science in Finland 61: 73-78.

Peltovuori, T., Uusitalo, R. \& Kauppila, T. 2002. Phosphorus reserves and apparent phosphorus saturation in four weakly developed cultivated pedons. Geoderma 110: 35-47.

Pote, D.H., Daniel, T.C., Nichols, D.J., Sharpley, A.N., Moore, P.A., Jr., Miller, D.M. \& Edwards, D.R. 1999. Relationship between phosphorus levels in three ultisols and phosphorus concentrations in runoff. Journal of Environmental Quality 28: 170-175.

Puustinen, M., Merilä, E., Palko, J. \& Seuna, P. 1994. Kuivatustila, viljelykäytäntö ja vesistökuormitukseen vaikuttavat ominaisuudet Suomen pelloilla. Abstract: Drainage level, cultivation practices and factors affecting load on waterways in Finnish farmland. Publications of National Board of Waters and the Environment - Series $A$ 198. $319 \mathrm{p}$.

Rodrigues, D. \& Mendoza, R. 1993. Readsorption of phosphate by soil during acid and alkaline extractions. Communications in Soil Science and Plant Analysis 24: 133-147.

Saarela, I., Kakkonen, K. \& Salo, Y. 2000. Savimaan fosforin saatavuuden parantaminen runsaalla kalkituksella sekä ruokamullan ja fosforin syvämultauksella. Abstract: Improving the availability of phosphorus in clay soils by heavy liming and by deep incorporation of topsoil and phosphorus. Publications of Agricultural Research Centre of Finland. Serie A 87. 51 p.
Sibbesen, E. \& Sharpley, A.N. 1997. Setting and justifying upper critical limits for phosphorus in soils. In: Tunney, H. et al. (eds.). Phosphorus loss from soil to water. Wallingworth: CAB International. p. 151-176.

Sharpley, A.N. 1985. Depth of surface soil-runoff interaction as affected by rainfall, soil slope, and management. Soil Science Society of America Journal 49: 1010-1015.

Sharpley, A.N., Syers, J.K. \& Tillman, R.W. 1978. An improved soil-sampling procedure for the prediction of dissolved inorganic phosphate concentration in surface runoff from pasture. Journal of Environmental Quality 7: 455-456.

Turtola, E. \& Yli-Halla, M. 1999. Fate of phosphorus applied in slurry and mineral fertilizer: accumulation in soil and release into surface runoff water. Nutrient Cycling in Agroecosystems 55: 165-174.

Urvas, L. \& Jussila, M. 1979. Rivilannoituksen vaikutus viljavuustutkimuksen tulokseen. Maatalouden Tutkimuskeskus, Maantutkimuslaitos, Tiedote 7. 9 p.

Uusitalo, R. \& Tuhkanen, H.-R. 2000. Phosphorus saturation of Finnish soils: evaluating an easy oxalate extraction method. Agricultural and Food Science in Finland 9: 61-70.

Vuorinen, J. \& Mäkitie, O. 1955. The method of soil testing in use in Finland. Agrogeological Publications No 63. p. 1-44.

Yli-Halla, M., Hartikainen, H., Ekholm, P., Turtola, E. Puustinen, M. \& Kallio, K. 1995. Assessment of dissolved phosphorus in surface runoff by soil analysis. Agriculture, Ecosystems and Environment 56: 5362.

Yli-Halla, M., Nykänen, A., Siimes, K. \& Tuhkanen, H.-R. 2001. Ympäristötuen ehdot ja maan helppoliukoisen fosforin pitoisuus. Abstract: Agri-Environmental Programme regulations and the easily soluble phosphorus concentration in soil. MTT Publications. Series $A$ 77. $45 \mathrm{p}$. 
Vol. 11 (2002): 371-379.

\title{
SELOSTUS
}

\section{Muokkauskerrokseen sekoitetun pohjamaan vaikutus maasta uuttuvan fosforin määrään}

\author{
Tommi Peltovuori \\ Helsingin yliopisto
}

Tutkimuksessa selvitettiin muokkauskerroksesta otettaviin maanäytteisiin mahdollisesti joutuvan pohjamaan vaikutusta näytteestä tehtävien fosforianalyysien tuloksiin. Samalla tutkittiin mahdollisuuksia pienentää runsaasti fosforia sisältävästä muokkauskerroksesta vapautuvan liukoisen fosforin määrää sekoittamalla siihen fosforia tehokkaasti pidättävää pohjamaata.

Kuudesta viljellystä maaprofiilista otettiin maanäytteet muokkauskerroksesta ja muokkauskerroksen alapuolisesta pohjamaasta. Puhtaista maanäytteistä ja maanäyteseoksista, jotka sisälsivät 25 tai $50 \%$ pohjamaata, analysoitiin viljavuusfosfori, fosforin kyllästysaste ja fosforin Q/I-kuvaaja. Seoksista mitattuja analyysituloksia verrattiin muokkauskerroksen ja pohjamaan analyysitulosten massaosuuksilla painotettuihin keskiarvoihin.

Viljavuusfosforin ja fosforin kyllästysasteen osalta maanäyteseoksista mitatut ja puhtaiden näytteiden tulosten perusteella lasketut arvot olivat hyvin lähellä toisiaan. Pohjamaan osuuden kasvaessa maanäyteseoksessa viljavuusfosforitulos ja fosforin kyllästysaste pienenivät lineaarisesti $\left(r^{2}>0,85\right)$. Lineaarisen riippuvuuden perusteella maanäyteseoksen analyysitulos voidaan ennustaa, mikäli puhtaiden näytteiden tulokset ja maiden sekoitussuhde tiedetään. Vesiuuttoisen fosforin kohdalla seoksista mitatut arvot olivat sen sijaan huomattavasti pienempiä kuin alkuperäisten pinta- ja pohjamaanäytteiden perusteella lasketut tulokset, ja vesiuuttoisen fosforin pitoisuus sekä fosforin Q/I-kuvaajien avulla lasketut tasapainopitoisuudet pienenivät hyvin nopeasti pohjamaan osuuden kasvaessa maanäyteseoksessa. Pohjamaan voimakas taipumus pienentää vesiliukoisen fosforin määrää ja fosforin tasapainopitoisuutta seoksessa saattaa tarjota mahdollisuuden pienentää fosforin liukoisuutta runsaasti fosforia sisältävissä maissa syvämuokkauksen avulla, ja siten vähentää välittömästi rehevöitymistä aiheuttavan liukoisen fosforin huuhtoutumista vesistöihin pintavalunnan mukana. 